\title{
Using StratasamplerTM Multi-Level Wells to Examine the Hyporheic Zone within a Riparian Wetland
}

by

\author{
D. L. Dunn
}

Westinghouse Savannah River Company

Savannah River Site

Aiken, South Carolina 29808

K. L. Dixon

R. L. Nichols

A. Schwartzman

R. Roseberry

DOE Contract No. DE-AC09-96SR18500

This paper was prepared in connection with work done under the above contract number with the $U$. $S$. Department of Energy. By acceptance of this paper, the publisher and/or recipient acknowledges the U.S. Government's right to retain a nonexclusive, royalty-free license in and to any copyright covering this paper, along with the right to reproduce and to authorize others to reproduce all or part of the copyrighted paper.

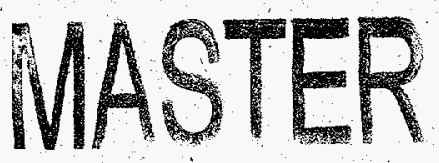




\section{DISCLAIMER}

This report was prepared as an account of work sponsored by an agency of the United States Government. Neither the United States Government nor any agency thereof, nor any of their employees, makes any warranty, express or implied, or assumes any legal liability or responsibility for the accuracy, completeness, or usefulness of any information, apparatus, product, or process disclosed, or represents that its use would not infringe privately owned rights. Reference herein to any specific commercial product, process, or service by trade name, trademark, manufacturer, or otherwise does not necessarily constitute or imply its endorsement, recommendation, or favoring by the United States Government or any agency thereof. The views and opinions of authors expressed herein do not necessarily state or reflect those of the United States Government or any agency thereof.

This report has been reproduced directly from the best available copy.

Available to DOE and DOE contractors from the Office of Scientific and Technical Information, P.O. Box 62, Oak Ridge, TN 37831; prices available from (615) 576-8401.

Available to the public from the National Technical Information Service, U.S. Department of Commerce, 5285 Port Royal Road, Springfield, VA 22161. 


\section{DISCLAIMER}

Portions of this document may be illegible electronic image products. Images are produced from the best available original document. 


\title{
USING STRATASAMPLER ${ }^{\text {TM }}$ MULTI-LEVEL WELLS TO EXAMINE THE HYPORHEIC ZONE WITHIN A RIPARIAN WETLAND
}

\author{
D. L. Dunn, K. L. Dixon, R. L. Nichols, A. Schwartzman, R. Roseberry \\ Savannah River Technology Center \\ Building 773-42A \\ Aiken, South Carolina 29808
}

\begin{abstract}
The hyporheic zone is the distinct transition region between groundwater and surface water. The characteristics of this groundwater-surface water interface, which extends both vertically and laterally, are functionally and structurally significant to the hydrology and ecology of a riparian wetland.

The initial objectives of this research are to establish a baseline and monitor the influences of local scale hydrology and biogeochemical behavior within the hyporheic zone at an unimpacted, uncontaminated site. A riparian wetland site along the headwaters of Fourmile Branch has been selected. Multi-level wells have been installed at thirteen locations along the headwaters of the Fourmile Branch at the groundwater-surface water interface site. Four of the multi-level wells have three StrataSamplers ${ }^{\mathrm{TM}}$ and nine of the wells have two StrataSamplers ${ }^{\mathrm{TM}}$.

Six of the thirteen multi-level wells were installed by hand auger in October, 1997. Hydrographs for the StrataSamplers ${ }^{\mathrm{TM}}$ show that the samplers were successfully isolated from each other as indicated by consistent differences in water levels. The water quality in these zones is also consistently different and provides additional evidence that the materials and methods selected for installation of the multi-level wells were successful in establishing depth discrete groundwater sampling points that are isolated from each other.
\end{abstract}

This network of multi-level wells will facilitate planned studies of the hyporheic zone, the groundwater-surface water interface, and will enable us to develop methods applicable at impacted sites.

\section{Background}

The hyporheic zone is the distinct transition region between groundwater and surface water. The characteristics of this groundwater-surface water interface, which extends both vertically and laterally, are functionally and structurally significant to the hydrology and ecology of a riparian wetland.

The initial objectives of this research are to establish a baseline and monitor the influences of local scale hydrology and biogeochemical behavior within the hyporheic zone at an unimpacted, uncontaminated site. A riparian wetland site along the headwaters of Fourmile Branch has been selected. Thirteen multi-level wells were installed and equipped with StrataSamplers ${ }^{\mathrm{TM}}$ to allow for depth discrete water level measurements, and for the collection of depth discrete groundwater samples. Instrumentation at the site includes a data logger for the collection of climatological and water level data and an automated sampler for the collection of routine surface water samples.

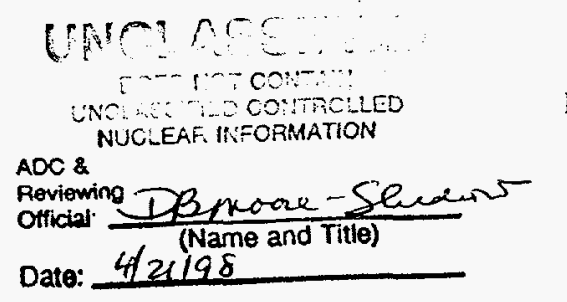


The collection of multi-disciplinary data should significantly strengthen our understanding of contaminant transport mechanisms as controlled by the integrated effect of natural processes and surface chemistry as it occurs at the groundwater-surface water interface.

\section{Study Site}

Fourmile Branch originates in the center of the Savannah River Site and flows 24.2 miles (39 $\mathrm{km}$ ), draining into the Savannah River at river mile 152.1. Fourmile Branch drains a watershed of approximately 22 miles $^{2}\left(57 \mathrm{~km}^{2}\right)$, including several SRS facilities: C Area (Reactor), F and $\mathrm{H}$ Areas (separations and seepage basins), and the Solid Waste Disposal Facility (SWDF). Fourmile Branch receives process effluents from F- and H-Area operations. Fourmile Branch also receives effluent from $C$ Area which included heated Savannah River water from C Reactor before it was placed on standby in 1985 . The reference location chosen for this study is along the headwaters of the Fourmile Branch and has no known history of contamination (Figure 1).

\section{Materials and Methods}

The multi-level wells used for this project have been equipped with Depth Discrete Sämpling Ports (DDSP). See Figure 2. The design of the DDSP allows the collection of discrete samples from several depths within a single borehole. The StrataSampler ${ }^{\mathrm{TM}}$ DDSP is manufactured by Timco Mfg., Inc. and is constructed of stainless steel components common in the groundwater monitoring industry. These components include slotted or wire wrapped well screens, flush joint threads (i.e. Triloc ${ }^{\mathrm{TM}}$ ) and sample tube, see attached Figure 2. The pass-through is also made of stainless steel. A sample chamber is formed by sealing the annulus between the well screen and pass-through with a continuous tungsten inert gas (TIG) weld. A TIG weld is also used to connect the sample tube to the sample chamber. Flexible tubing is connected to the sample tube using a standard stainless steel compression fitting such as a Swagelok fitting. These fittings are designed to provide leak proof connections for process, power, and instrumentation applications. Samples are pumped individually from the sample chamber to the surface.

\section{Installation}

Multi-level wells were installed at 6 locations using a 3.75 inch diameter hand auger in October 1997. Each multi-level well included $2-3$ StrataSamplers ${ }^{\text {TM }}$, PVC casing and polyethylene tubing. In some cases temporary casing was used to stabilize the borehole during placement of the StrataSamplers ${ }^{\mathrm{TM}}$, casing, and backfill materials. The location of each StrataSampler ${ }^{\mathrm{TM}}$ was determined in the field based on lithologic description, Appendix A, of the material collected during hand augering. StrataSamplers ${ }^{\mathrm{TM}}$ were placed at permeable sediment depths identified in the lithologic descriptions. See Figure 3 for a representative view of two well heads at the site.

Two inch diameter PVC well casing is used to properly arrange the StrataSamplers ${ }^{\mathrm{TM}}$ in each borehole. Polyethylene tubing, color coded for identification purposes, has been connected to each StrataSampler ${ }^{\mathrm{TM}}$ and extended to the surface. Filter packs were installed around each StrataSampler ${ }^{\mathrm{TM}}$ using Foster Dixiana FX50 sand $(.45-.55 \mathrm{~mm}$ grain size). Bentonite pellets 
were placed between StrataSamplers ${ }^{\mathrm{TM}}$ to prevent vertical leakage in the borehole. See Figure 2 and Appendix 2.

Vibracoring was used to install multi-level wells at 7 additional locations in January 1998. Vibracoring consisted of vibrating a core barrel made of 15 feet of 3 inch diameter aluminum pipe into the ground and extracting it using a winch. The recovered core barrel was split open and a lithologic description of the contents was prepared. A second aluminum tube was vibrated into the resulting borehole as a temporary casing to prevent hole collapse. A two-inch hand auger was used to clean out the cased borehole. The multi-level well was assembled and placed in the cased borehole with the StrataSampler ${ }^{\mathrm{TM}}$ screen zones aligned with the depth of the permeable layers. Filter sand was poured around the multi-level well and within the cased borehole to coincide with the screened zones. Bentonite pellets were poured around the multilevel well and within the cased borehole to seal between the screened zones. Sand and bentonite layers were alternated as needed to provide a filter pack at the screened intervals and seals to prevent vertical mixing within the borehole. The three inch casing was slowly extracted to allow settling and collapse around the multi-level well. Each multi-level well was constructed from the materials described above.

\section{Sampling and Measurements}

Water levels were measured one to two times per week in each of the StrataSamplers ${ }^{\text {TM }}$ installed in October 1997. These measurements are presented in Table 2 and Figures 4 -9. . Hydrographs for the StrataSamplers ${ }^{\mathrm{TM}}$ installed in October show that the samplers were successfully isolated from each other as indicated by the consistent differences in water levels, Figures 4 -9.

StrataSamplers ${ }^{\mathrm{TM}}$ 31F-R and 31F-Y, in multi-level well GSW031F had similar water levels as did StrataSamplers ${ }^{\mathrm{TM}}$ 33F-Y and 33F-G in multi-level well GSW033F. The water quality in these zones is consistently different, as shown below, and indicates that the StrataSamplers ${ }^{\mathrm{TM}}$ were successfully isolated from each other.

Water samples were collected from the stream and each of the StrataSamplers ${ }^{\text {TM }}$ installed in October 1997 at least once a week using a peristaltic pump. Water was pumped from each of the StrataSamplers ${ }^{\mathrm{TM}}$ until it appeared clear. After the murky water had been pumped from a StrataSampler ${ }^{\mathrm{TM}}$ a water sample was collected for measurement of $\mathrm{pH}$ and specific conductivity The results of the $\mathrm{pH}$ and specific conductivity measurements are presented in Table 3 . The $\mathrm{pH}$ and conductivity probes were calibrated prior to taking readings each day. Figures 10 and 11 show the time series for specific conductivity measurements in multi-level wells $31 \mathrm{~F}$ and $33 \mathrm{~F}$. The specific conductivity of samples collected from StrataSampler ${ }^{\text {TM }} 31 \mathrm{~F}-\mathrm{R}$ is consistently higher than the specific conductivity of samples collected from StrataSampler ${ }^{\text {TM }} 31 \mathrm{~F}-\mathrm{Y}$ which indicates that that there is no leakage between these samples. A similar trend was observed for StrataSamplers ${ }^{\mathrm{TM}} 33 \mathrm{~F}-\mathrm{Y}$ and 33F-G, Figure 11, as well as in the other multi-level wells, Table 3.

Once the water sample for $\mathrm{pH}$ and conductivity readings was collected, an AquaPrep ${ }^{\mathrm{TM}} 0.45 \mu \mathrm{m}$ single use, groundwater sampling filter was attached to the discharge tubing on the peristaltic pump. The sampled water was pumped through the filter and into two $250 \mathrm{ml}$ vials. An acid 
preserved sample was sent to be analyzed for target analyte metals and the second water sample was analyzed by ion chromatography for anions (chloride, fluoride, formate, nitrate, nitrite, oxalate, phosphate, and sulfate).

\section{Results}

Multi-level wells have been installed at thirteen locations along the headwaters of the Fourmile Branch at the groundwater-surface water interface site. Four of the multi-level wells have three StrataSamplers ${ }^{\mathrm{TM}}$ and nine of the wells have two StrataSamplers ${ }^{\mathrm{TM}}$.

Six multi-level wells were installed by hand auger in October, 1997. See Table 1. Field Geologic Logs (OSR 30-3) and Well Construction Diagrams were prepared and are included as Appendix 1 and Appendix 2 respectively. Hydrographs for the StrataSamplers ${ }^{\text {TM }}$ installed in October 1997 show that the samplers were successfully isolated from each other as indicated by consistent differences in water levels, Figures 4 -9. The water quality in these zones is also consistently different and provides additional evidence that the materials and methods selected for installation of the multi-level wells were successful in establishing depth discrete groundwater sampling points that are isolated from each. The results from analyses of the trace metals and anions are not yet complete and will not be included in this report.

This network of multi-level wells will facilitate planned studies of the hyporheic zone, the groundwater-surface water interface, and will enable us to develop methods applicable at impacted sites. 
Figure 1

\section{Groundwater/Surface Water Interface Project Location}
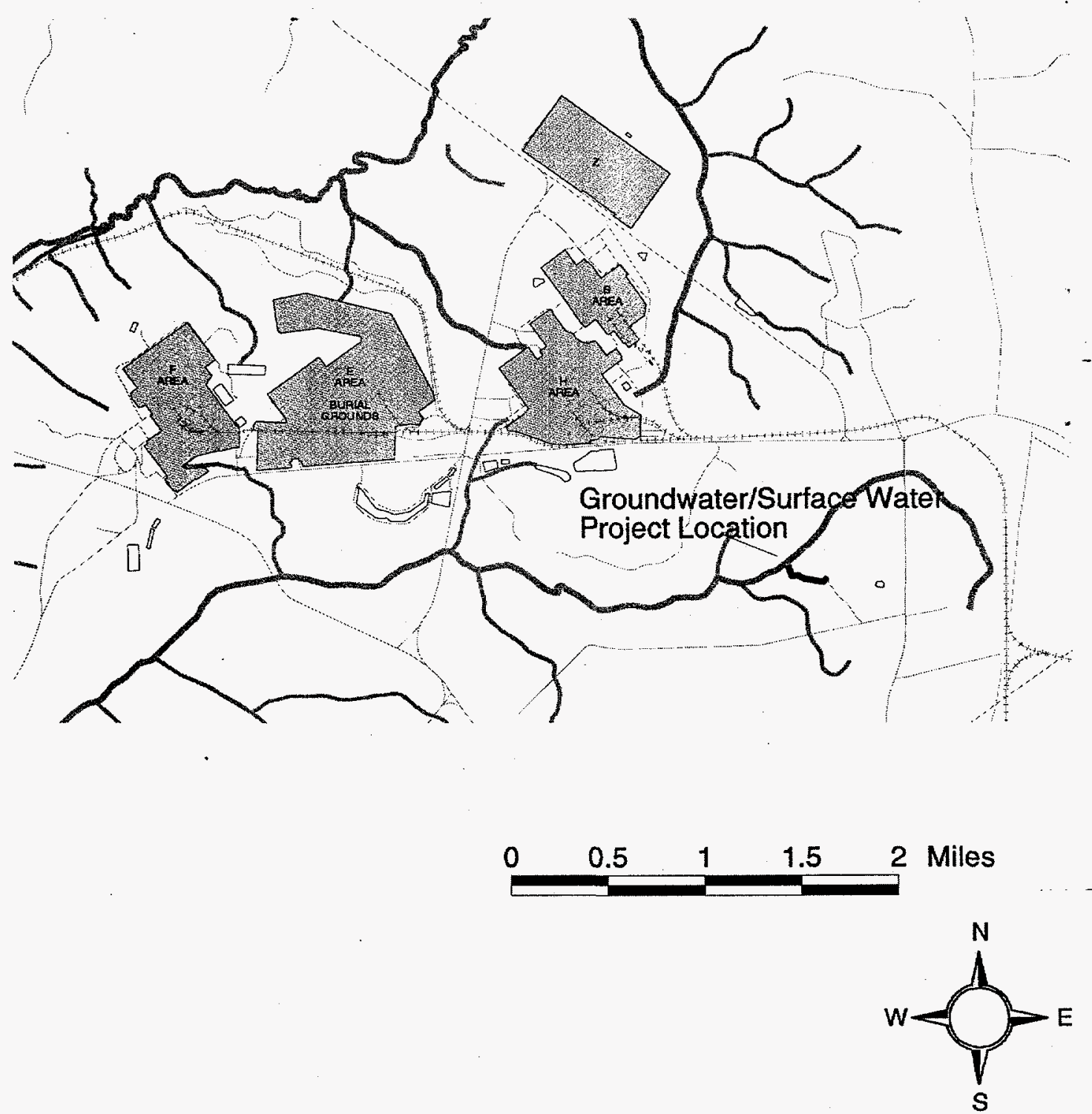
Figure 2

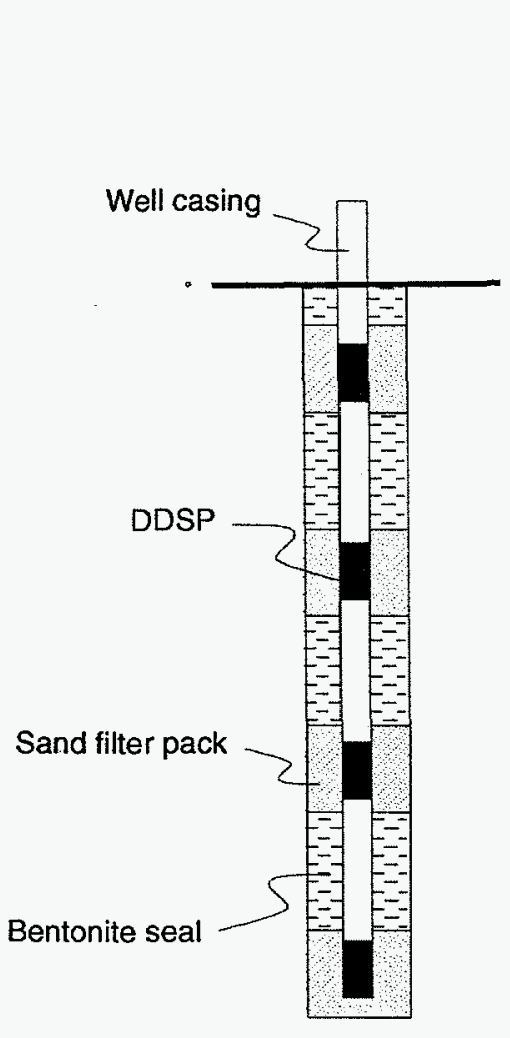

Sampling tube,

$9.53 \mathrm{~mm}, 316 \mathrm{SS}$

Title: Depth Discrete Sampling Port

Sketch No.: SKS-RLN-98-001

Originator: R. L. Nichols

Date: .02 .05 .98 
Figure 3. Photograph of well heads for GSW013C (right) and GSW019D (left).

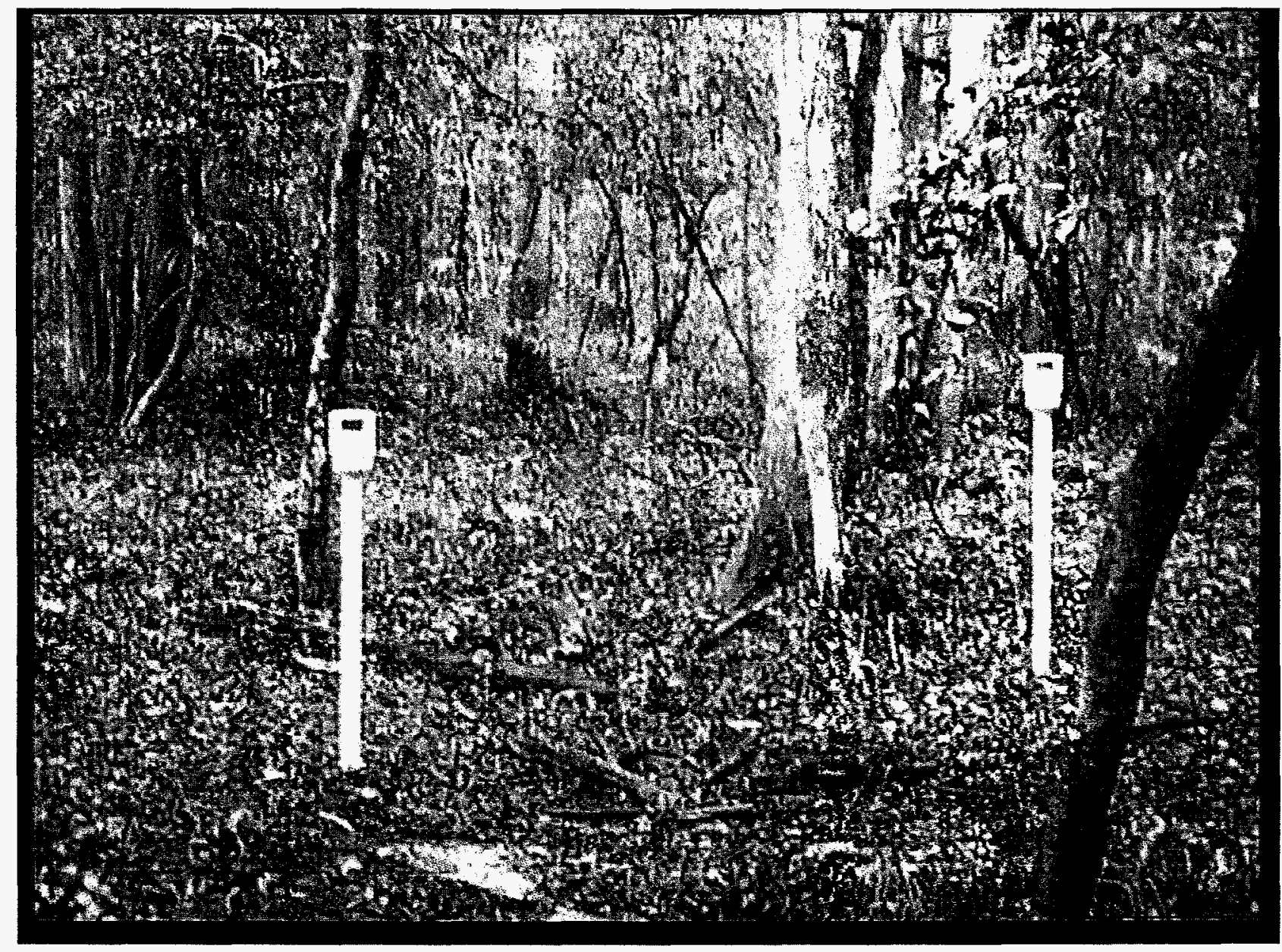


Table 1 Well construction details for multi-level wells.

\begin{tabular}{|c|c|c|c|c|c|c|c|}
\hline Well ID & $\begin{array}{l}\text { SRS } \\
\text { North }\end{array}$ & $\begin{array}{l}\text { SRS } \\
\text { East }\end{array}$ & $\begin{array}{c}\text { Surface } \\
\text { Elevation } \\
(\mathrm{ft}, \mathrm{msl})\end{array}$ & $\begin{array}{l}\text { Stand Pipe } \\
\text { Elevation } \\
(\mathrm{ft}, \mathrm{msl})\end{array}$ & $\begin{array}{c}\text { StrataSampler } \\
\text { ID }\end{array}$ & $\begin{array}{c}\text { Depth to } \\
\text { Top of } \\
\text { Screen } \\
\text { (ft) }\end{array}$ & $\begin{array}{l}\text { Depth to } \\
\text { Bottom of } \\
\text { Screen } \\
\text { (ft) }\end{array}$ \\
\hline GSW013C & 64703.63 & 64324.1 & 247.8 & 251.85 & $\begin{array}{l}13 \mathrm{C}-\mathrm{R} \\
13 \mathrm{C}-\mathrm{Y}\end{array}$ & $\begin{array}{l}1.50 \\
9.00\end{array}$ & $\begin{array}{c}4.50 \\
10.00\end{array}$ \\
\hline GSW015C & 64683.37 & 64322.21 & 246.9 & 251.26 & $\begin{array}{l}15 \mathrm{C}-\mathrm{R} \\
15 \mathrm{C}-\mathrm{Y}\end{array}$ & $\begin{array}{l}0.50 \\
8.00\end{array}$ & $\begin{array}{l}3.50 \\
9.00\end{array}$ \\
\hline GSW018C & 64654.72 & 64319.27 & 248.8 & 252.78 & $\begin{array}{l}18 \mathrm{C}-\mathrm{R} \\
18 \mathrm{C}-\mathrm{Y}\end{array}$ & $\begin{array}{l}3.00 \\
8.00\end{array}$ & $\begin{array}{l}6.00 \\
9.00\end{array}$ \\
\hline GSW019D & 64703.7 & 64314.62 & 247.5 & 251.37 & $\begin{array}{l}19 D-R \\
19 D-Y\end{array}$ & $\begin{array}{l}1.80 \\
9.30\end{array}$ & $\begin{array}{c}4.80 \\
10.30\end{array}$ \\
\hline GSW031F & 64705.41 & 64294.7 & 247.4 & 251.66 & $\begin{array}{l}31 \mathrm{~F}-\mathrm{R} \\
31 \mathrm{~F}-\mathrm{Y}\end{array}$ & $\begin{array}{l}1.00 \\
8.50\end{array}$ & $\begin{array}{l}4.00 \\
9.50\end{array}$ \\
\hline GSW033F & 64686.98 & 64292.21 & 247.8 & 251.79 & $\begin{array}{l}33 F-R \\
33 F-Y \\
33 F-G\end{array}$ & $\begin{array}{c}0.67 \\
5.58 \\
10.50\end{array}$ & $\begin{array}{c}3.67 \\
6.58 \\
11.50\end{array}$ \\
\hline
\end{tabular}

Table 2 Water level elevations for StrataSamplers ${ }^{\mathrm{TM}}$.

\begin{tabular}{|c|c|c|c|c|c|c|c|c|c|c|c|c|c|c|}
\hline \multirow{3}{*}{$\begin{array}{c}\text { Well } \\
\text { ID }\end{array}$} & \multicolumn{14}{|c|}{ Date } \\
\hline & $10 / 6$ & $10 / 7$ & $10 / 9$ & $10 / 15$ & $10 / 20$ & $10 / 21$ & $10 / 23$ & $10 / 27$ & $10 / 28$ & $10 / 30$ & $11 / 3$ & $11 / 5$ & $11 / 6$ & $11 / 7$ \\
\hline & \multicolumn{14}{|c|}{ Water Level (ft, msl) } \\
\hline $13 \mathrm{C}-\mathrm{R}$ & 246.27 & 245.93 & 246.18 & 246.35 & 246.77 & 246.68 & 246.85 & 247.18 & 246.85 & 246.68 & 246.85 & 246.85 & 246.85 & 246.85 \\
\hline $13 \mathrm{C}-\mathrm{Y}$ & 246.85 & 246.68 & 246.85 & 246.68 & 247.26 & 247.18 & 247.35 & 247.52 & 247.35 & 247.35 & 247.35 & 247.35 & 247.35 & 247.35 \\
\hline 15C-R & 246.59 & 246.76 & 246.59 & 246.26 & 246.59 & 246.59 & 246.76 & 247.01 & 246.84 & 246.76 & 246.93 & 246.76 & 246.76 & 246.76 \\
\hline $15 \mathrm{C}-\mathrm{Y}$ & 246.81 & 246.73 & 246.81 & 246.81 & 247.23 & 247.06 & 247.23 & 247.56 & 247.40 & 247.56 & 247.40 & 247.23 & 247.40 & 247.48 \\
\hline $18 \mathrm{C}-\mathrm{R}$ & 252.78 & 246.53 & 246.61 & 246.61 & 246.95 & 246.61 & 246.95 & 247.53 & 247.28 & 247.11 & 247.11 & 246.95 & 246.95 & 247.03 \\
\hline $18 \mathrm{C}-\mathrm{Y}$ & & & & & This : & as & & & $\mathrm{nrod}$ & water. & & & & \\
\hline 19D-R & 246.29 & 245.95 & 246.04 & 246.20 & 246.70 & 246.54 & 246.70 & 247.04 & 246.79 & 246.70 & 246.70 & 246.70 & 246.54 & 246.79 \\
\hline $19 D-Y$ & 246.84 & 246.67 & 246.67 & 246.67 & 247.17 & 247.01 & 247.17 & 247.51 & 247.26 & 247.17 & 247.34 & 247.34 & 247.17 & 247.26 \\
\hline $31 \mathrm{~F}-\mathrm{R}$ & 246.49 & 246.33 & 246.49 & 246.49 & 246.99 & 246.83 & 246.99 & 247.16 & 246.99 & 246.99 & 246.99 & 246.99 & 246.83 & 246.99 \\
\hline $31 \mathrm{~F}-\mathrm{Y}$ & 247.34 & 246.42 & 246.50 & 246.50 & 247.00 & 246.84 & 247.00 & 247.17 & 247.17 & 247.00 & 247.17 & 247.17 & 247.00 & 247.09 \\
\hline 33F-R & 251.79 & 245.96 & 248.04 & 245.96 & 246.29 & 246.12 & 246.29 & 246.54 & 246.29 & 246.29 & 246.29 & 246.29 & 246.12 & 246.21 \\
\hline $33 F-Y$ & 251.78 & 246.45 & 246.45 & 246.45 & 246.95 & 246.95 & 246.95 & 247.28 & 247.11 & 246.95 & 247.11 & 246.95 & 246.95 & 247.11 \\
\hline $33 \mathrm{~F}-\mathrm{G}$ & 251.77 & 251.77 & 246.44 & 246.44 & 247.10 & 246.94 & 246.94 & 247.27 & 247.10 & 246.94 & 247.10 & 247.10 & 247.10 & 247.10 \\
\hline
\end{tabular}


Table 3 Results from measurement of $\mathrm{pH}$ and specific conductivity of samples collected from StrataSamplers ${ }^{\top \mathrm{M}}$.

\begin{tabular}{|c|c|c|c|c|c|c|c|c|c|c|c|c|}
\hline \multirow[b]{3}{*}{ Well ID } & \multicolumn{12}{|c|}{ Date } \\
\hline & \multicolumn{2}{|c|}{ 8-Oct-97 } & \multicolumn{2}{|c|}{ 09-Oct-97 } & \multicolumn{2}{|c|}{ 20-Oct-97 } & \multicolumn{2}{|c|}{$23-$ Oct-97 } & \multicolumn{2}{|c|}{$30-$ Oct-97 } & \multicolumn{2}{|c|}{ 05-Nov-97 } \\
\hline & $\mathrm{pH}$ & Cond & $\mathrm{pH}$ & Cond & $\mathrm{pH}$ & Cond & $\mathrm{pH}$ & Cond & $\mathrm{pH}$ & Cond & $\mathrm{pH}$ & Cond \\
\hline $13 C-R$ & n.m. & 112.80 & n.m. & 100.50 & 5.71 & 178.20 & 5.61 & 116.90 & 6.31 & 180.00 & 7.70 & 52.30 \\
\hline $13 C-Y$ & n.m. & 19.29 & n.m. & 19.89 & 5.03 & 23.80 & 4.84 & 27.80 & 5.77 & 22.60 & 7.75 & 23.00 \\
\hline $15 \mathrm{C}-\mathrm{R}$ & n.m. & 149.50 & n.m. & 172.60 & 6.43 & 56.50 & 6.67 & 147.40 & 6.33 & 94.60 & 7.80 & 93.60 \\
\hline $15 \mathrm{C}-\mathrm{Y}$ & n.m. & 31.30 & n.m. & 28.90 & 5.45 & 24.60 & 5.75 & 27.10 & 5.75 & 27.80 & 7.81 & 28.30 \\
\hline $18 \mathrm{C}-\mathrm{R}$ & n.m. & 122.80 & n.m. & 125.30 & 5.92 & 48.20 & 6.19 & 40.10 & 6.30 & 34.40 & 7.84 & 33.30 \\
\hline 19D-R & n.m. & 67.20 & n.m. & 249.00 & 5.76 & 143.20 & 4.63 & 57.60 & 5.93 & 86.20 & 7.70 & 66.20 \\
\hline 19D-Y & n.m. & 24.90 & n.m. & 21.70 & 5.17 & 23.30 & 4.69 & 24.30 & 5.61 & 30.30 & 7.68 & 26.60 \\
\hline 31F-R & n.m. & 87.40 & n.m. & 70.10 & 5.94 & 91.30 & 5.66 & 65.10 & 6.24 & 57.30 & 7.67 & 64.50 \\
\hline $31 F-Y$ & n.m. & 18.39 & $\mathrm{n}, \mathrm{m}$. & 21.40 & 5.32 & 25.30 & 4.93 & 21.90 & 5.55 & 21.40 & 7.67 & 21.90 \\
\hline $33 F-R$ & n.m. & 80.10 & n.m. & 102.60 & .6 .26 & 416.00 & 6.15 & 31.30 & 6.39 & 216.00 & 7.77 & 85.80 \\
\hline 33F-Y & n.m. & 119.10 & n.m. & 138.60 & 6.52 & 105.30 & 6.32 & 81.70 & 3.00 & 64.30 & 7.81 & 100.60 \\
\hline $33 F-G$ & n.m. & 21.40 & n.m. & 29.70 & 5.14 & 26.30 & 4.80 & 25.20 & 5.61 & 25.90 & 7.87 & 24.60 \\
\hline
\end{tabular}

n.m.- not measured 
February 6, 1998

Figure 4

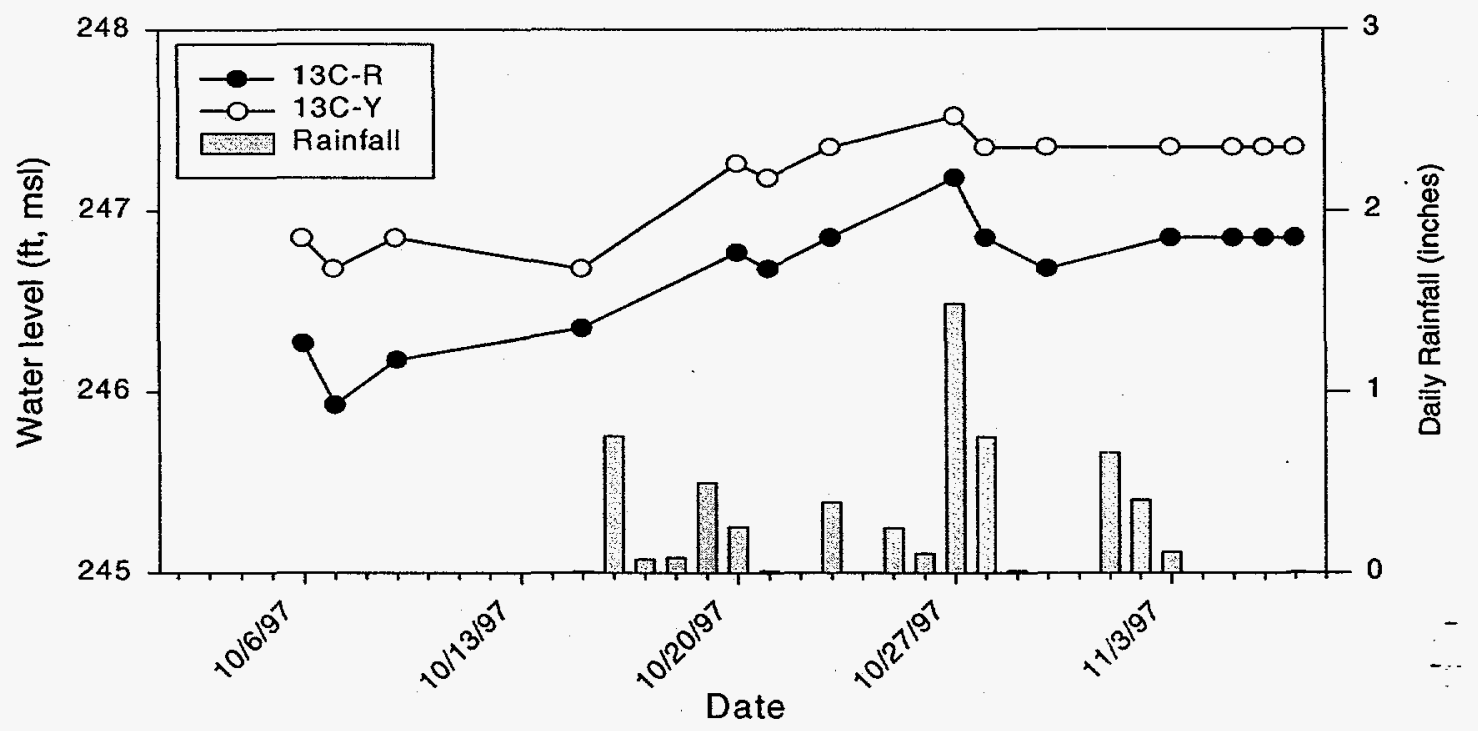

Figure 5

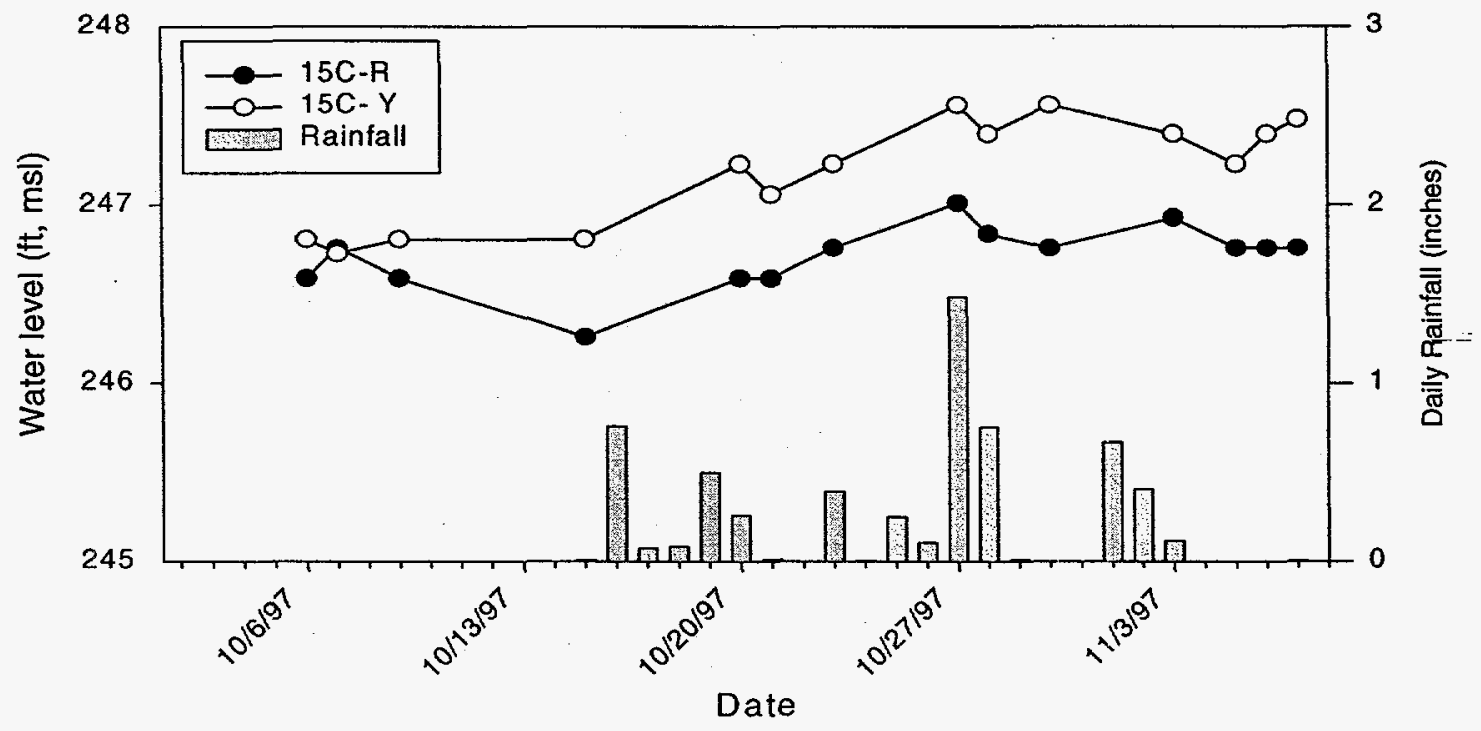


Figure 6

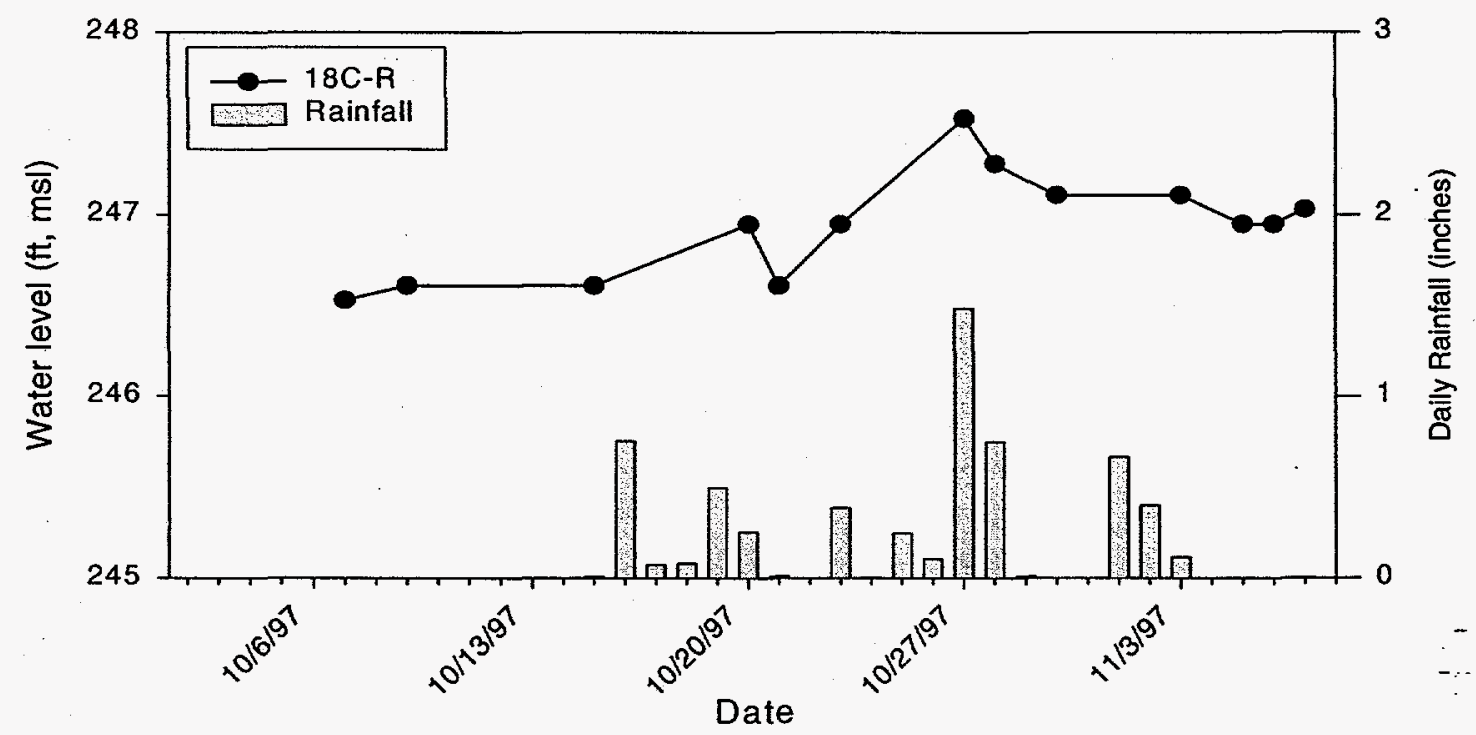

Figure 7

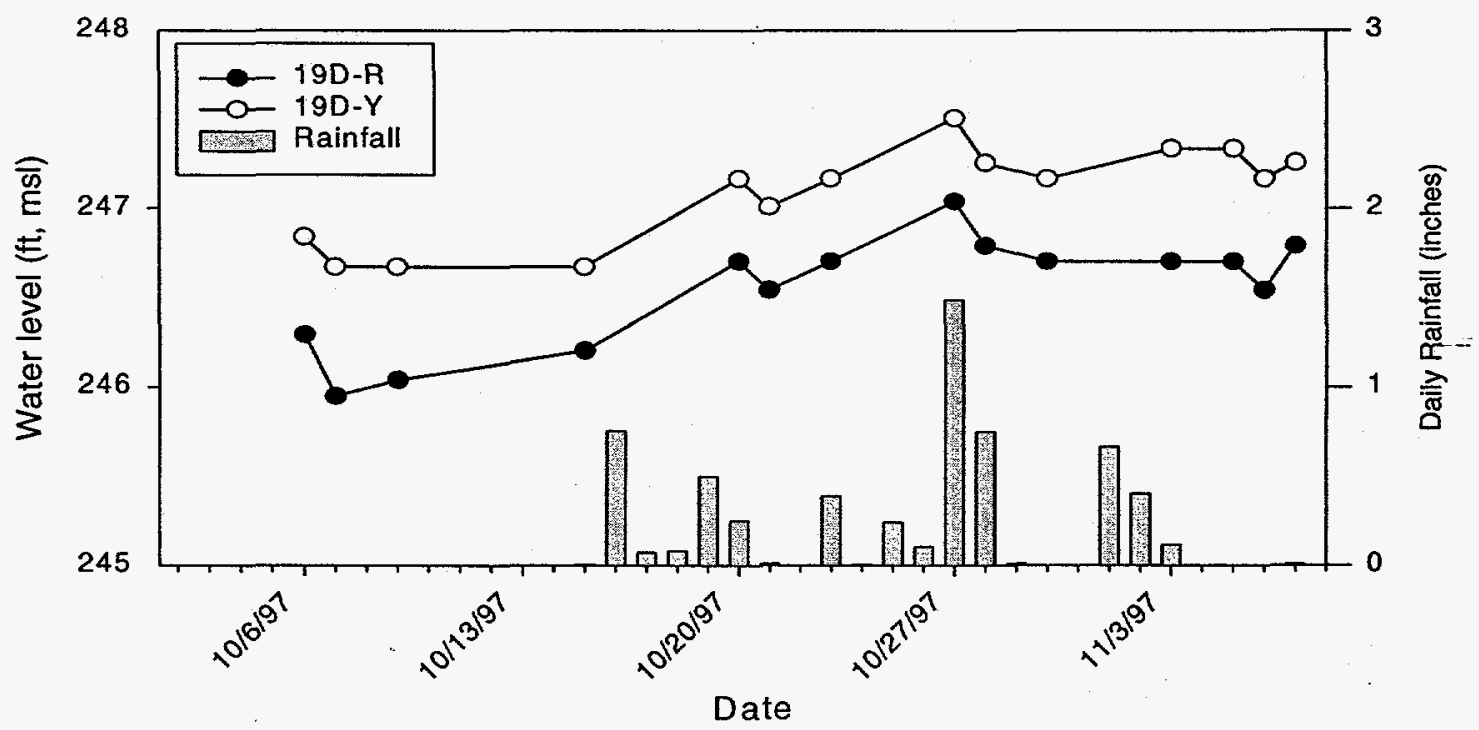


Figure 8

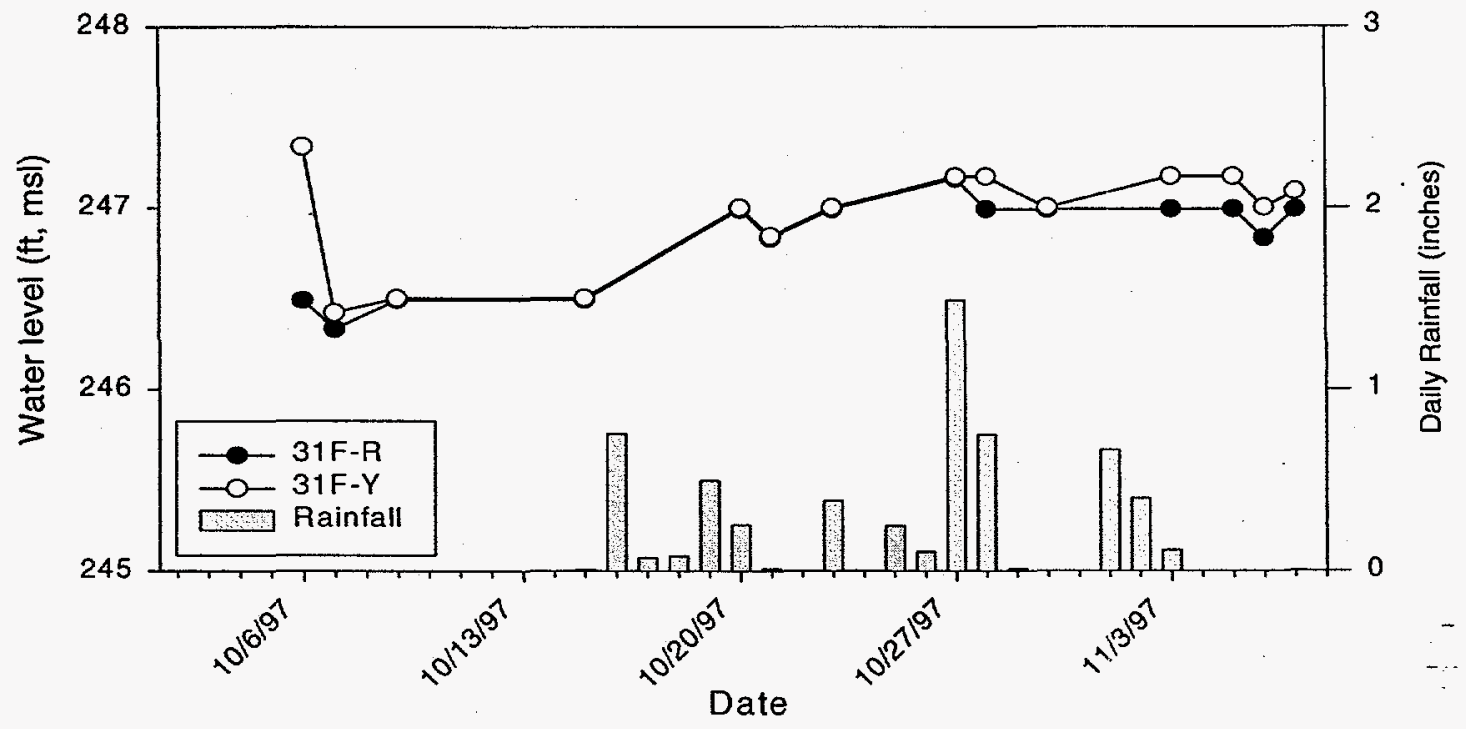

Figure 9

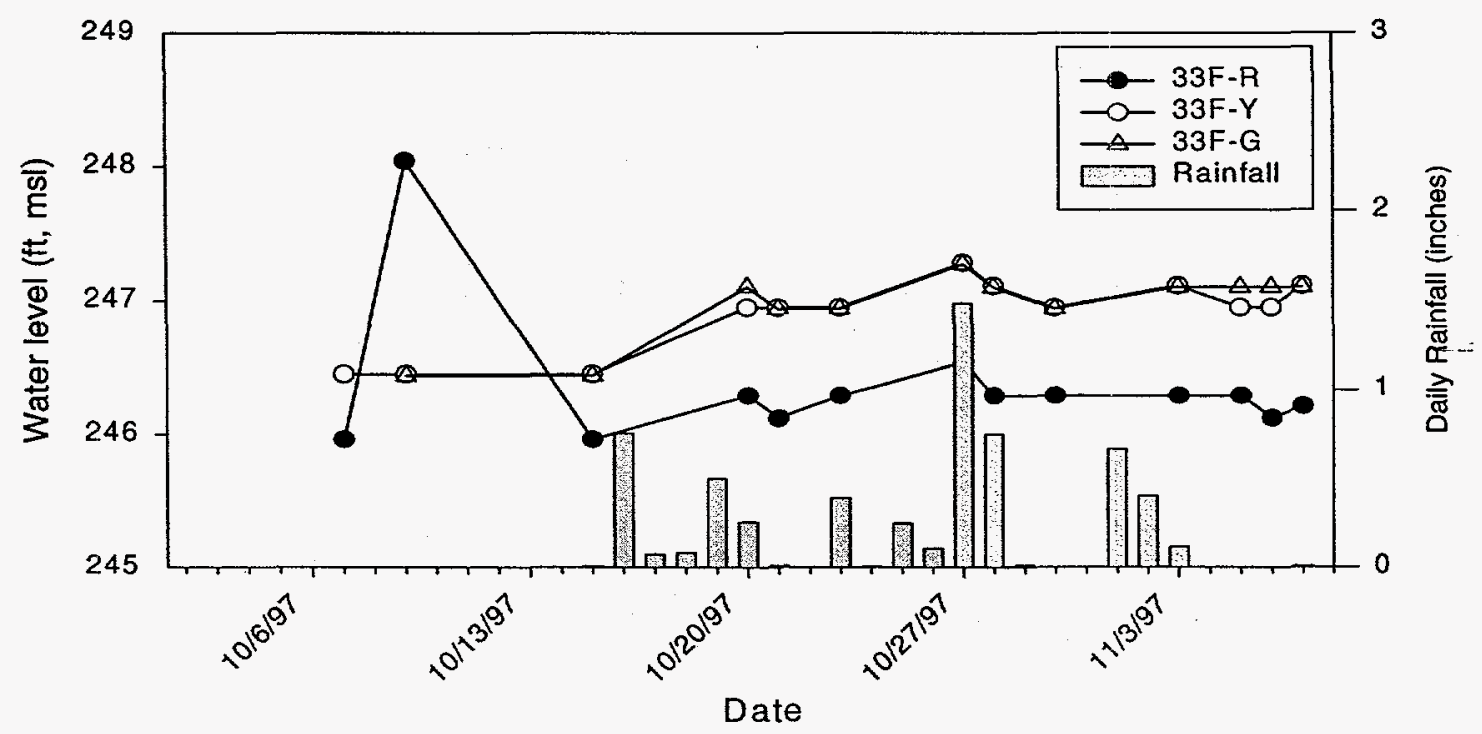


Figure 10

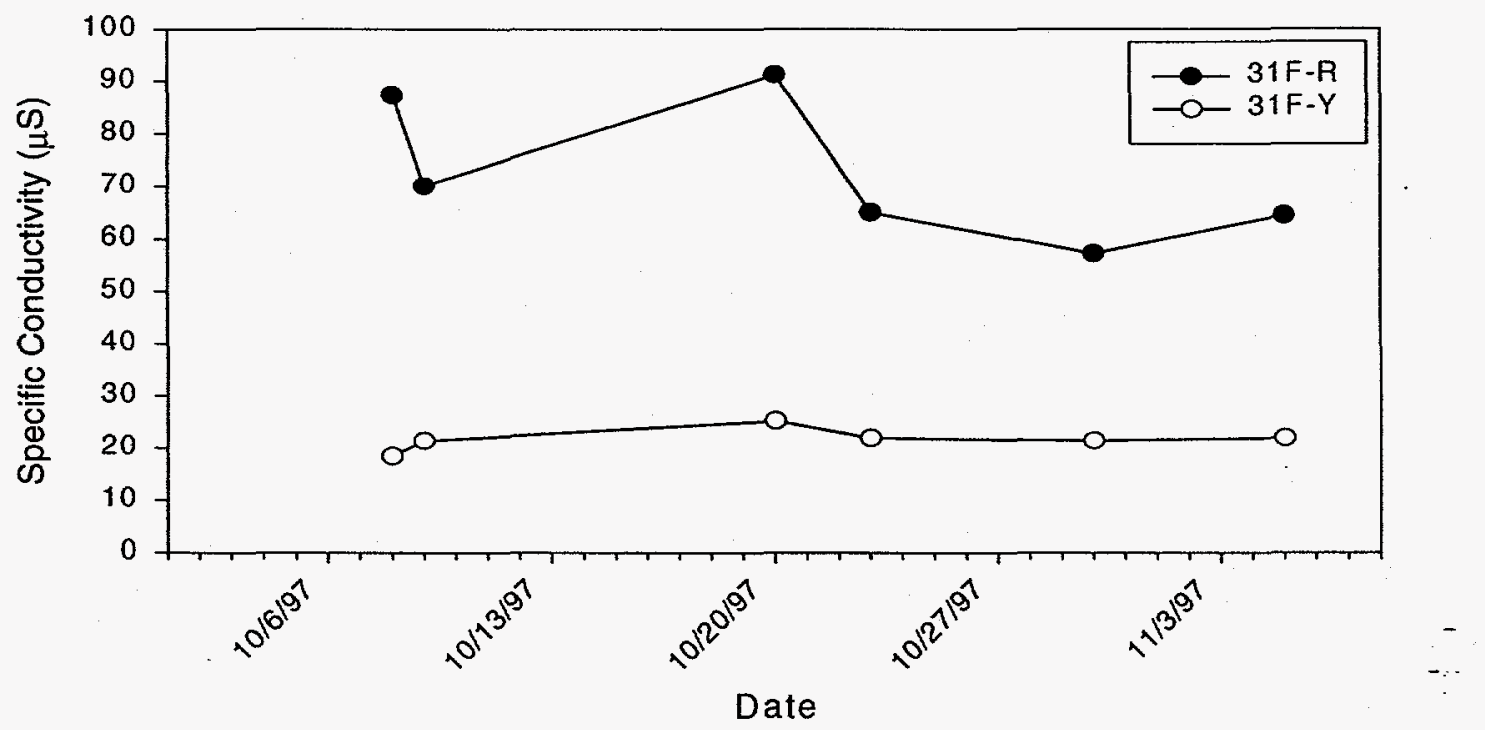

Figure 11

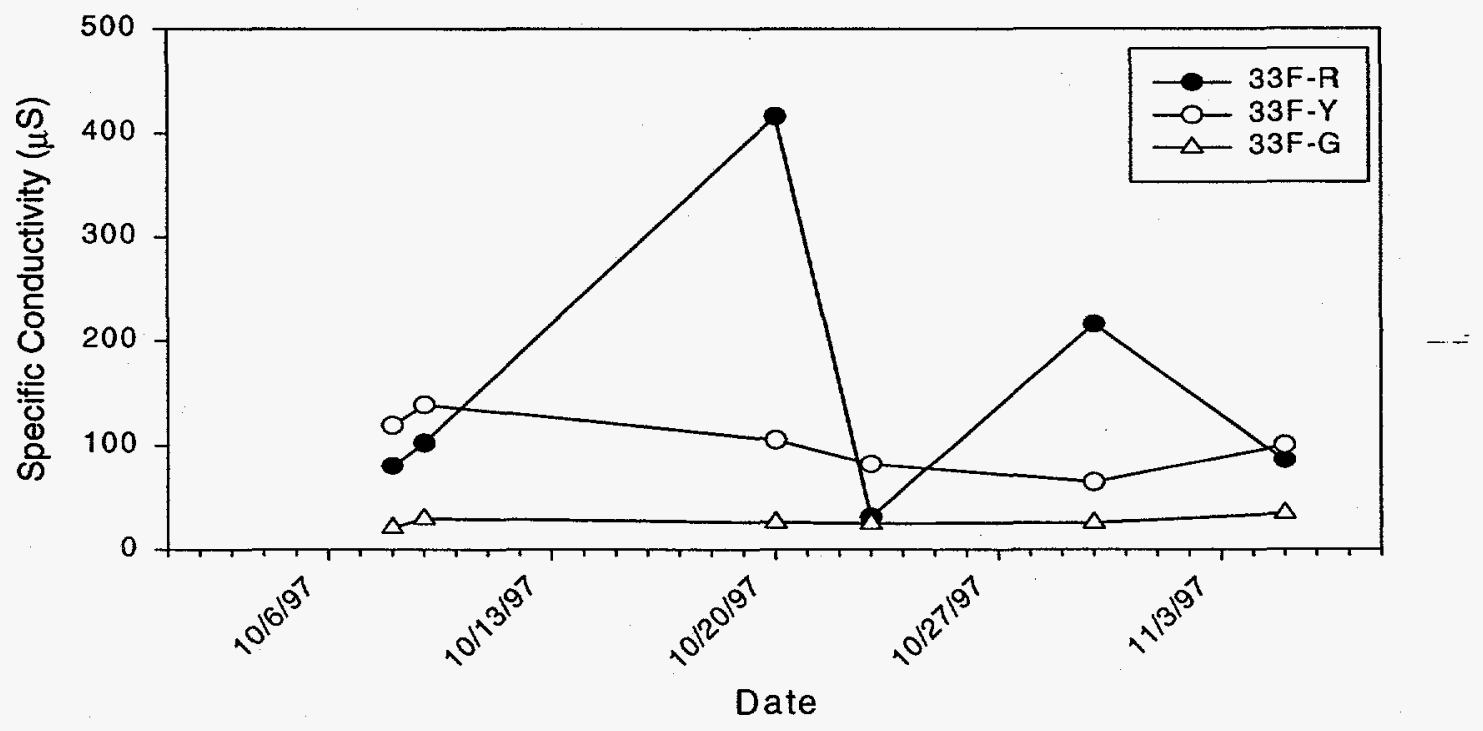


February 6, 1998

WSRC-TR-98-00046

Appendix 1 
S SRS"

FIELD GEOLOGIC LOG

acreasta moren sut

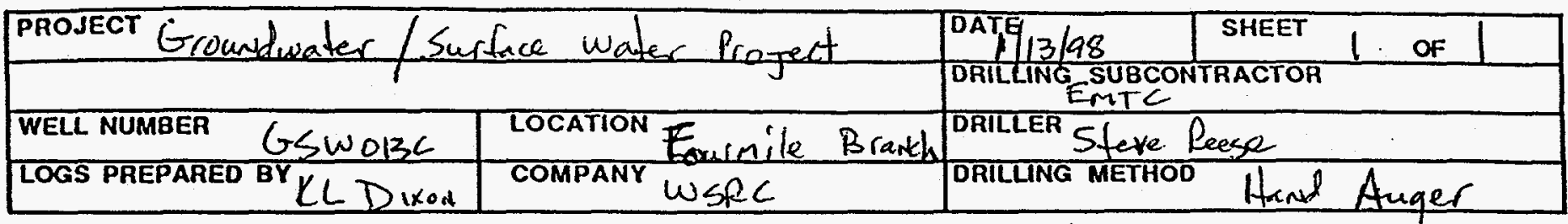

\begin{tabular}{|c|c|c|}
\hline 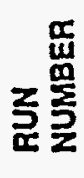 & $\begin{array}{l}\text { DEPTH } \\
\text { BELOW } \\
\text { GROUND } \\
\text { SURFACE } \\
\text { (FEET) }\end{array}$ & LITHOLOGY \\
\hline
\end{tabular}

SAMPLE DESCRIPTION

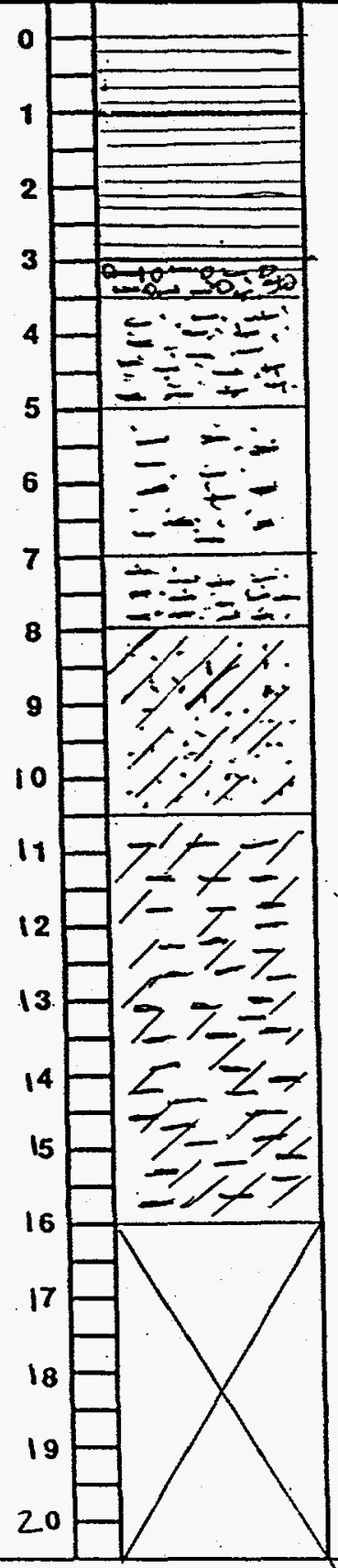
densley pocted-gray Sand - giky

grained with movy small pebbles sand. White with yellow nottles.
DRILLING COMMENTS/REMARKS

\begin{tabular}{|l|l|}
\hline $0-1^{\prime}$ Organic Clay-Brown & $0-1^{\prime}$ \\
\hline $1-3 \quad 4$ Lyy qfay & $1-3^{\prime}$ \\
\hline
\end{tabular}
$3-3 \cdot 5^{\prime}-$ Sandy clay podiuen grained Sand $3-3.5$
with pebbles-aray $3.5-5.0^{6}-$ Sandy clay - fine grained sand $3.5^{7}-5,0^{\circ}$

$5.0-7.0^{\prime}-\operatorname{Sandy}$ Clay - Medium qlained $5.0-7.0$

$7.0-8.0^{\prime}$ - Sandy Clan - Medium araived 7.0-8.0

sand Pcolly sorted with vany pebbles.

Increasing sand context neross anterval

$8-10.5^{\prime}$ Silly sand - Sand fraction $8-10.5$ poorly sorted piedominanth medium

$10.5-16^{\prime}$ - Silly day with very fine $10.5-16$ 


\section{FIELD GEOLOGIC LOG}

\begin{tabular}{|c|c|c|c|}
\hline PROJECT Ground water / Sur & ce water froject & \begin{tabular}{|l|l|l|} 
DATE & 13 & 48 \\
\end{tabular} & SHEET 1 OF 1 \\
\hline & & DRILLING SUBCON & RACTOR \\
\hline WELL NUMBER GSWO $15 \mathrm{C}$ & LOCATION Fourmile Branch & DRILLER Steve & keese \\
\hline LOGS PREPARED BY K.L.D $1 \times 0 \mathrm{~N}$ & COMPANY WSEC & DRILLING METHOD & Aand Aug \\
\hline
\end{tabular}

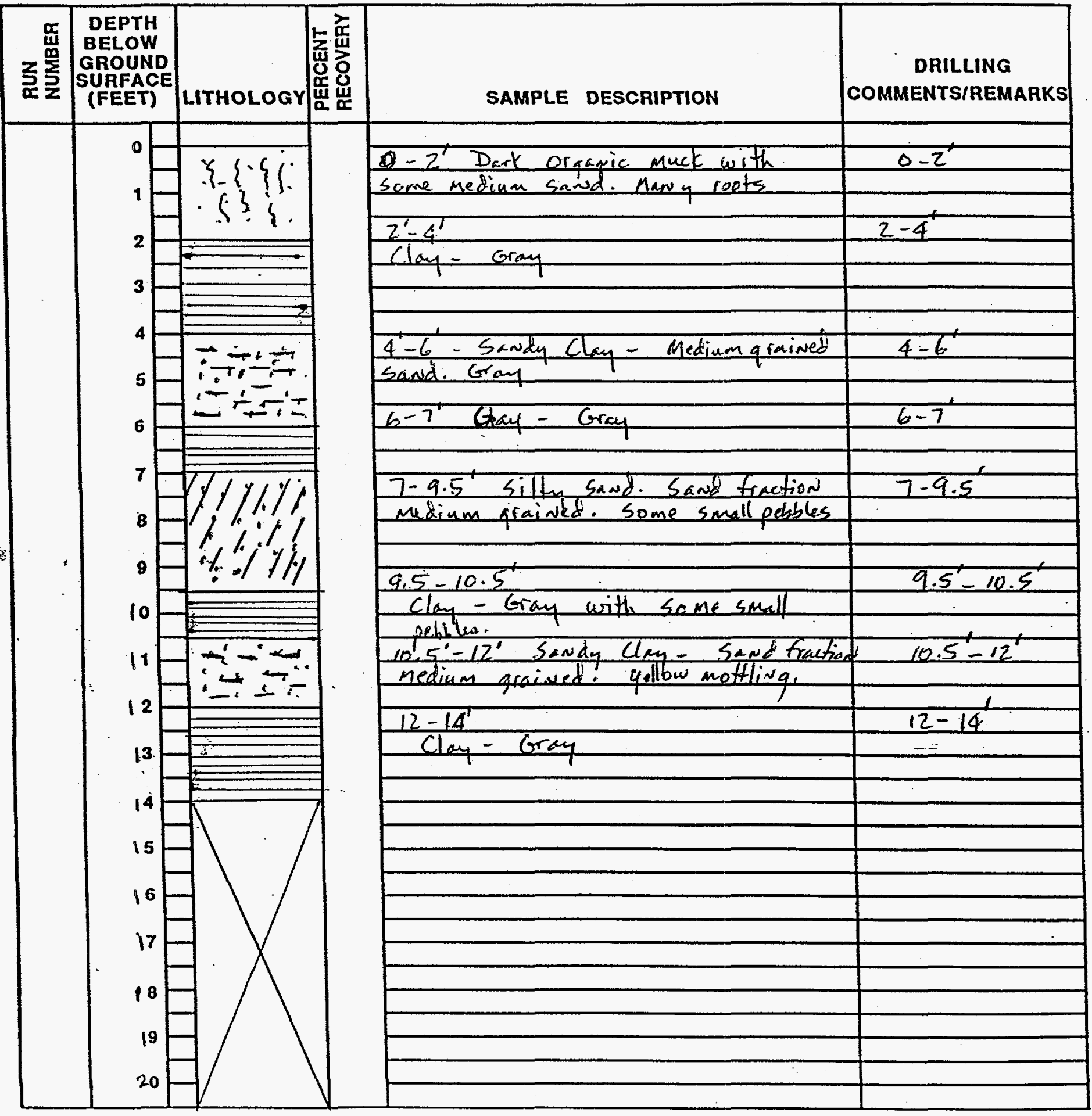




\section{FIELD GEOLOGIC LOG}

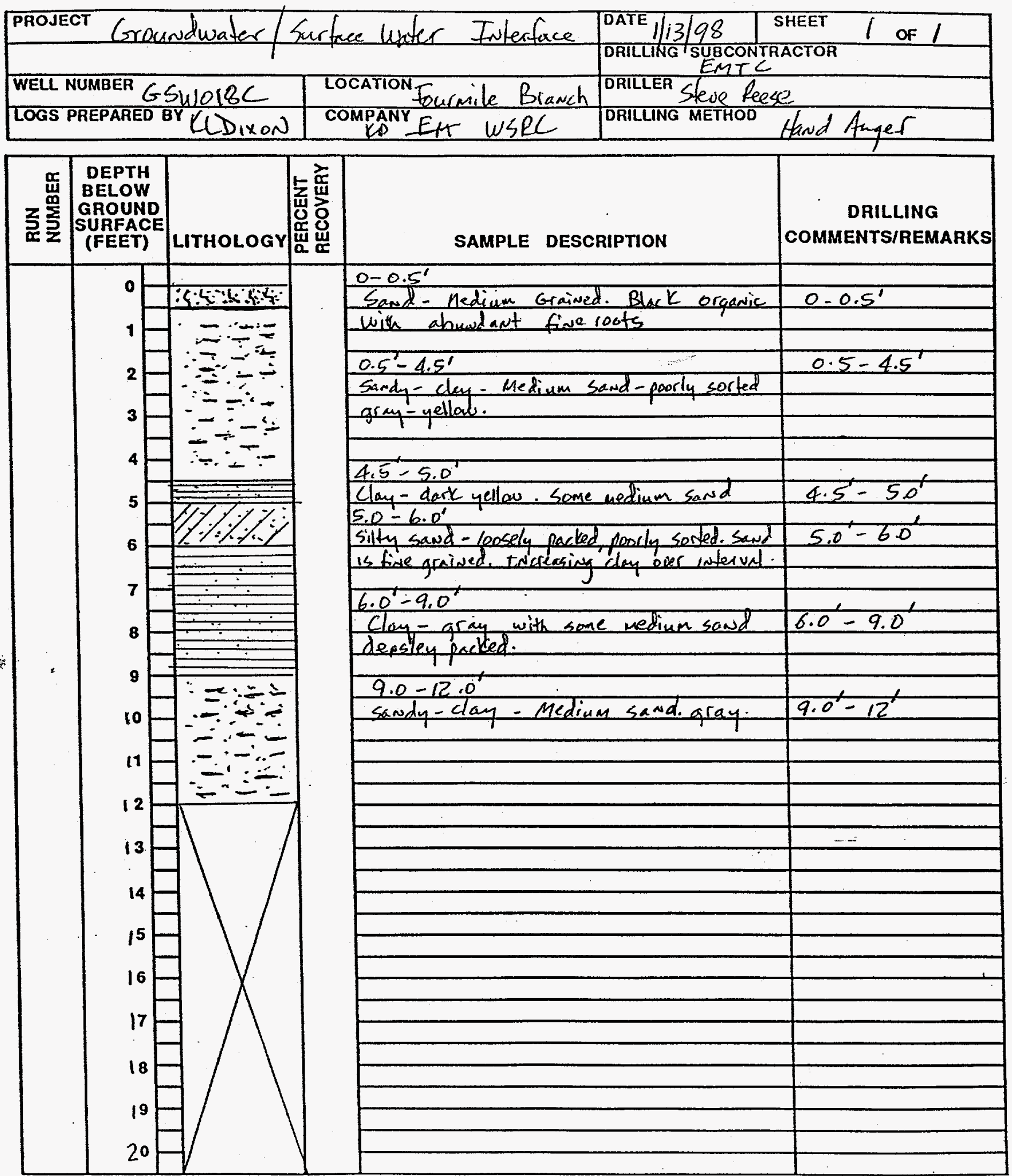


SPRS

\section{FIELD GEOLOGIC LOG}

\begin{tabular}{|c|c|c|}
\hline PROJECT Groundwater Surf & Surface wader Preject & DATE $/ / 3 / 98$ \\
\hline & & DRILLING SUBCONTAACTOR EMTC \\
\hline WELL NUMBER GSWO3IF & LOCATION Fol & DRILLER Sfleve \\
\hline LOGS PREPAREO BY $K L I$ & COMPANY WSRC & ORILLING METHOD Hand \\
\hline
\end{tabular}

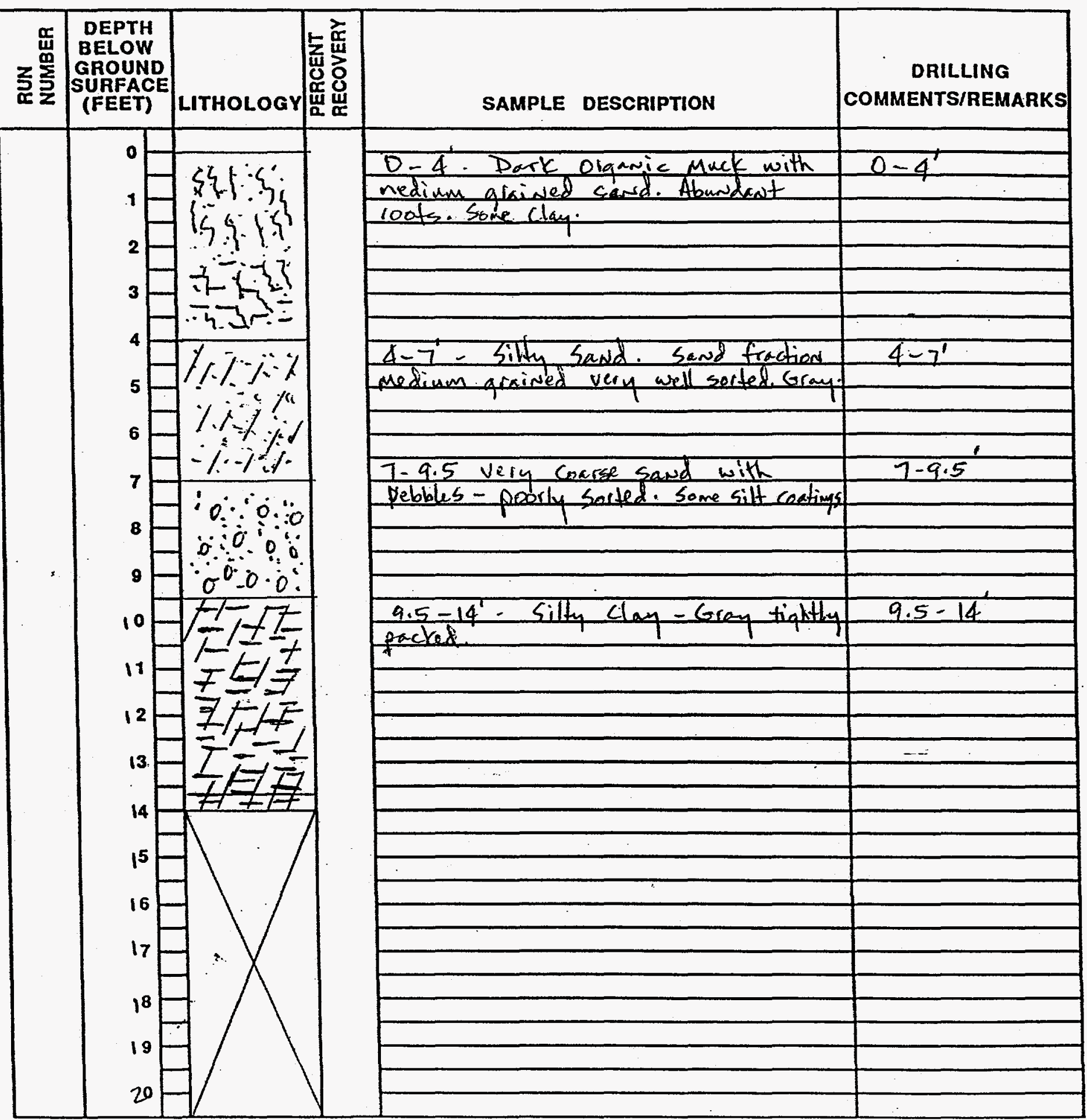




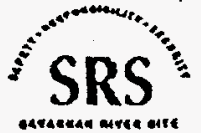

\section{FIELD GEOLOGIC LOG}

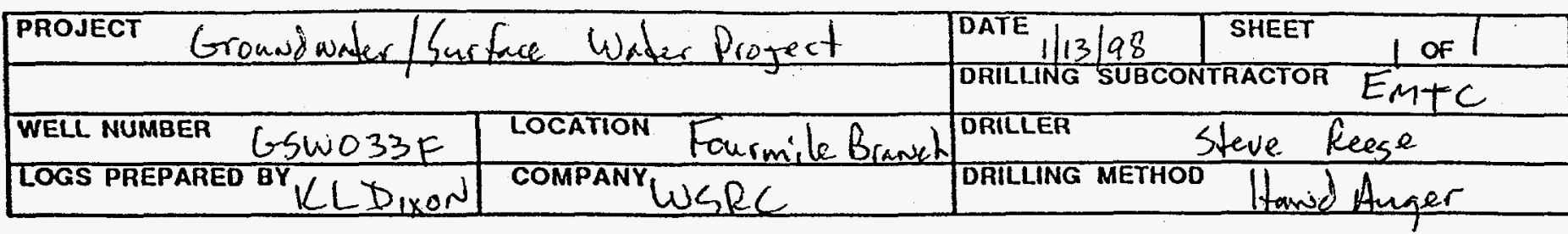

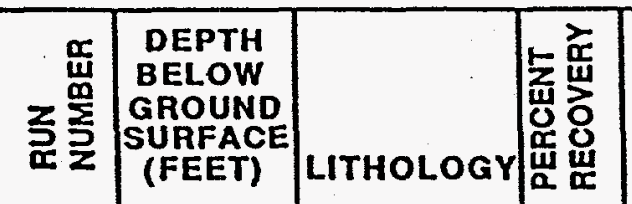

SAMPLE DESCRIPTION

DRILLING

COMMENTSIREMARKS

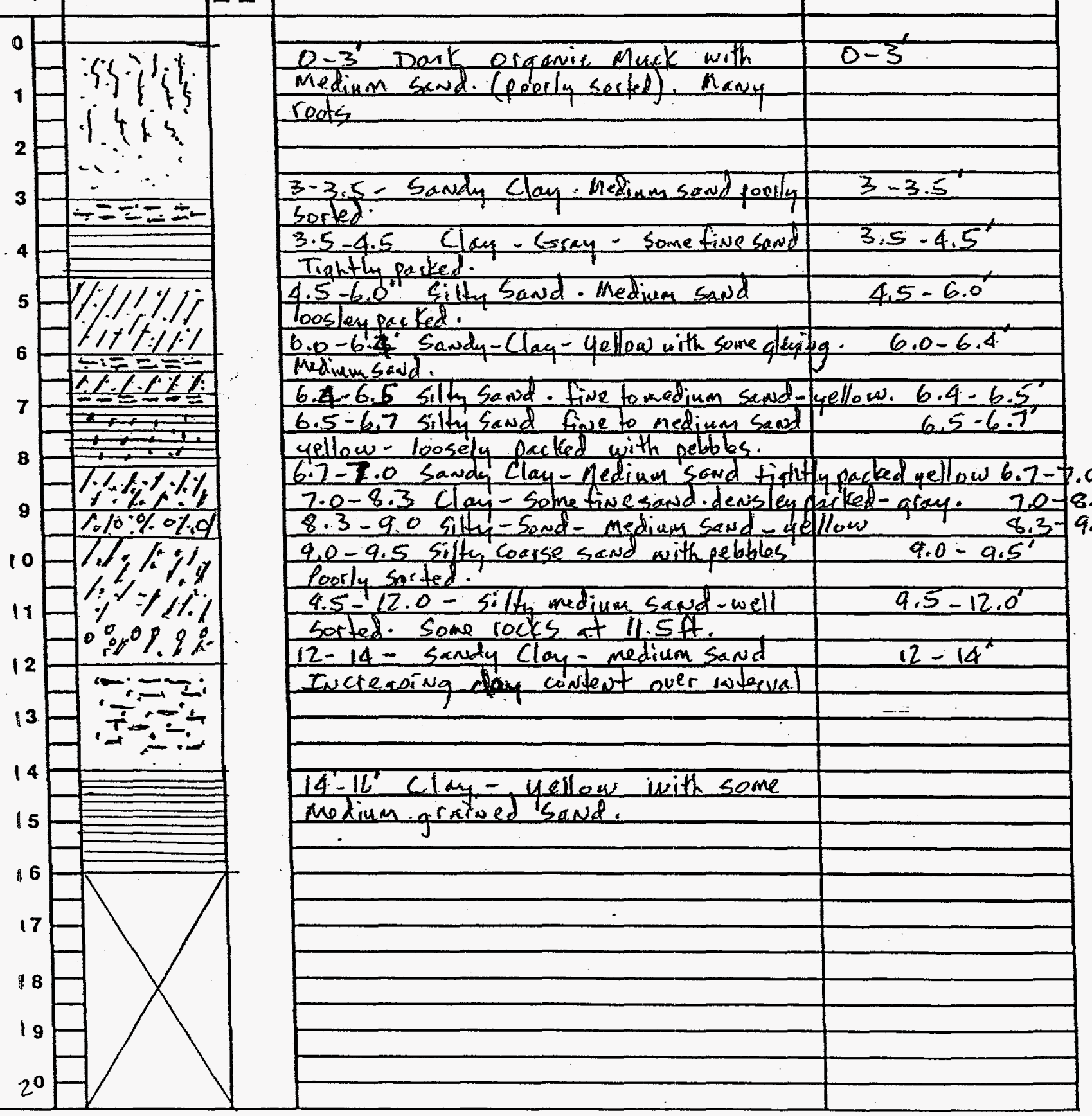


February 6, 1998

WSRC-TR-98-00046

Appendix 2 
Well Construction Diagram

\begin{tabular}{|l|l|l|}
\hline Well Number: GSwO13C & Date of Installation: $9 / 29 / 97$ & Horizontal Scale: $1: 3$ \\
\hline & & Vertical Scale: $1: 3$ \\
\hline SRS North: 64703.63 & SRS East: 64324.10 & Ground Elevation: 247.8 FT \\
\hline
\end{tabular}

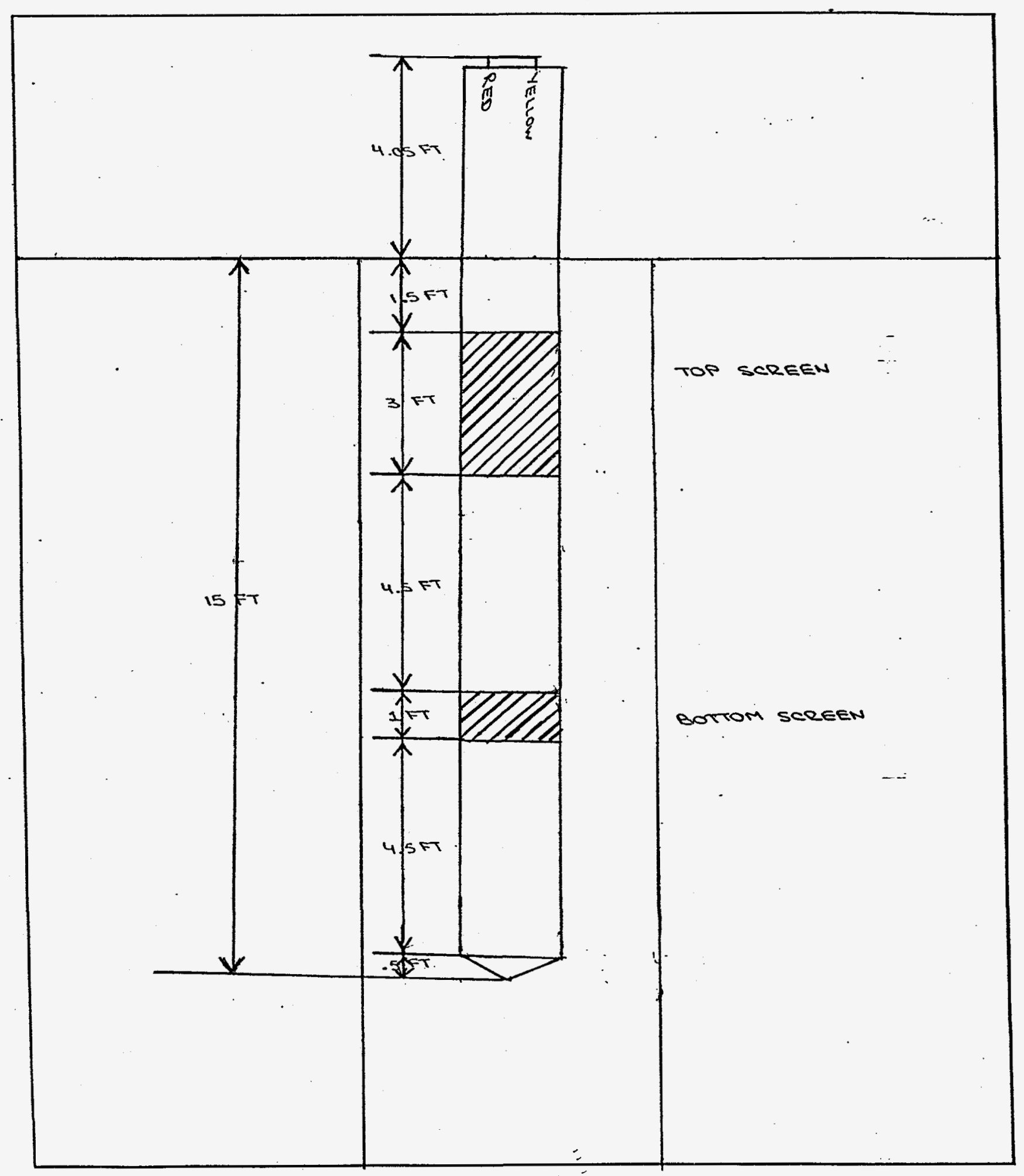




\section{Well Construction Diagram}

\begin{tabular}{|c|c|c|}
\hline Well Number: $G s$ & Date of Installation: $9 / 30 / 97$ & Horizontal Scale: $1: 2$ \\
\hline & & Vertical Scale: \\
\hline SRS North: 64683.37 & SRS East: 64322.21 & Ground Elevation: $246.9 \mathrm{FT}$ \\
\hline
\end{tabular}

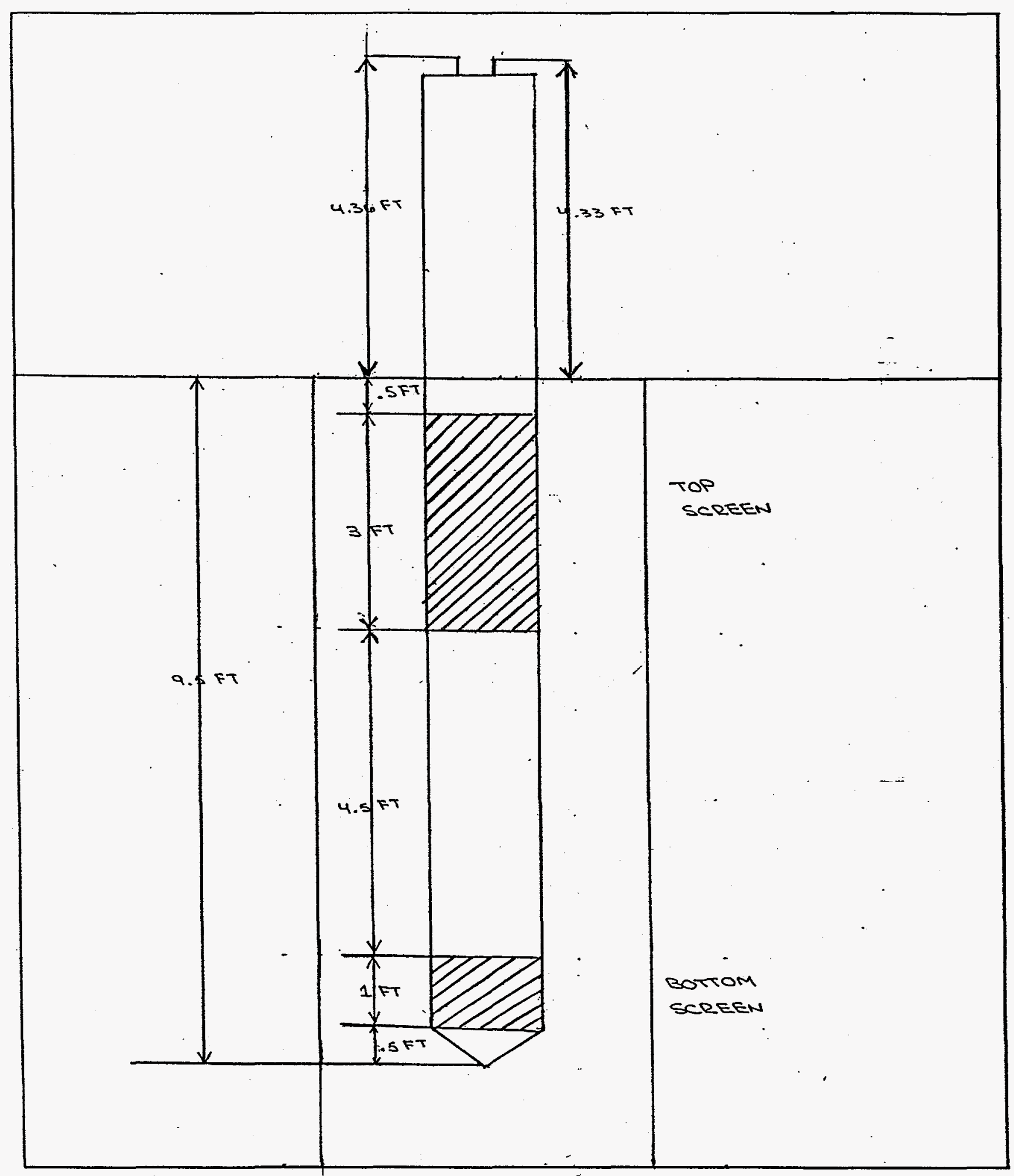




\section{Well Construction Diagram}

\begin{tabular}{|l|l|l|}
\hline Well Number: GSwol8c & Date of Installation: 10/7/97 & Horizontal Scale: $1: 2$ \\
\hline & & Vertical Scale: $1: 2$ \\
\hline SRS North: 64651.72 & SRS East: 64379.27 & Ground Elevation: $248.8 \mathrm{FT}$ \\
\hline
\end{tabular}

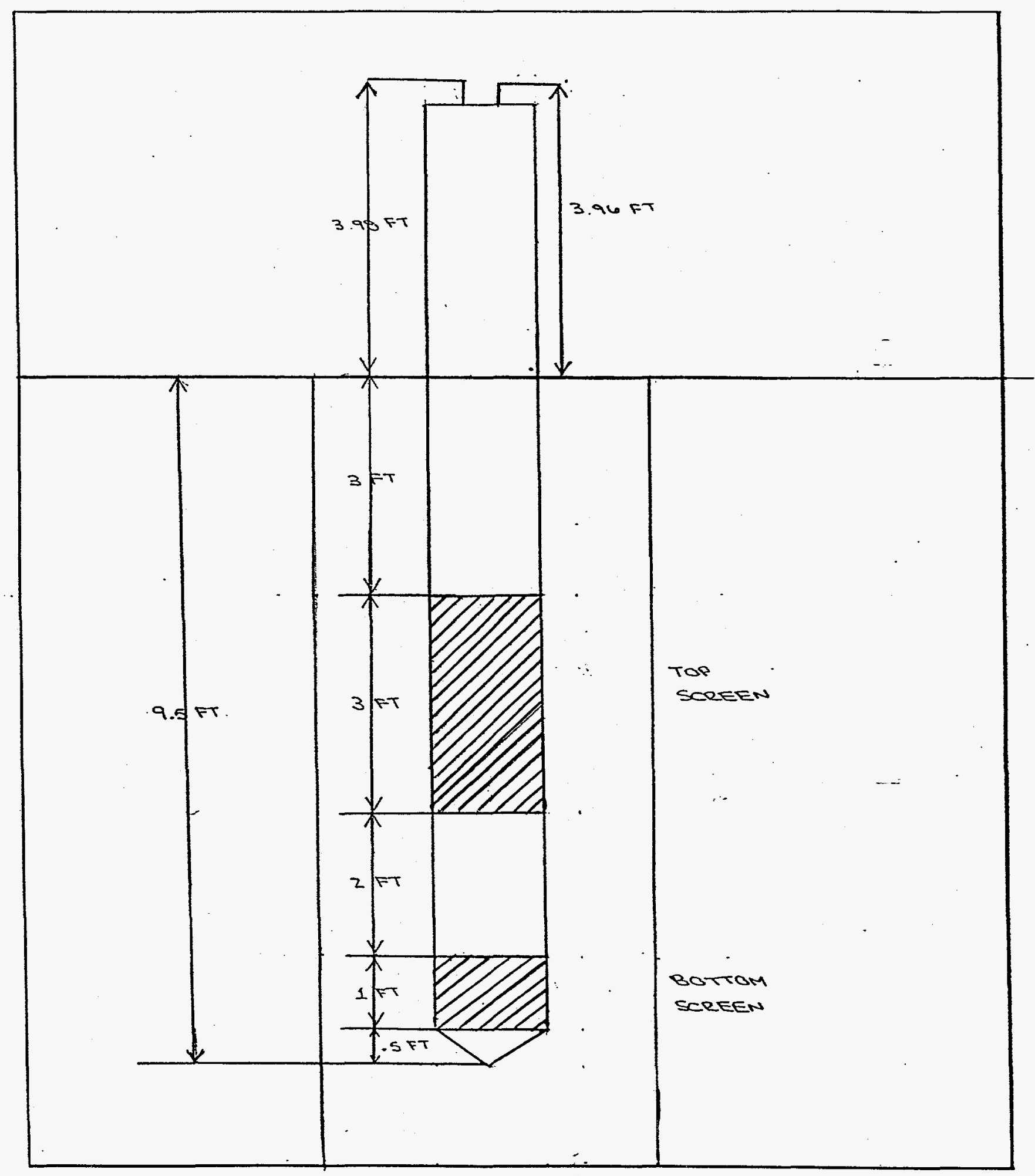




\section{Well Construction Diagram}

\begin{tabular}{|l|l|l|}
\hline Well Number: GSwo19D & Date of Installation: $9 / 24 / 97$ & Horizontal Scale: $1: 3$ \\
\hline SRS North: 64703.70 & & Vertical Scale: $1: 3$ \\
\hline
\end{tabular}

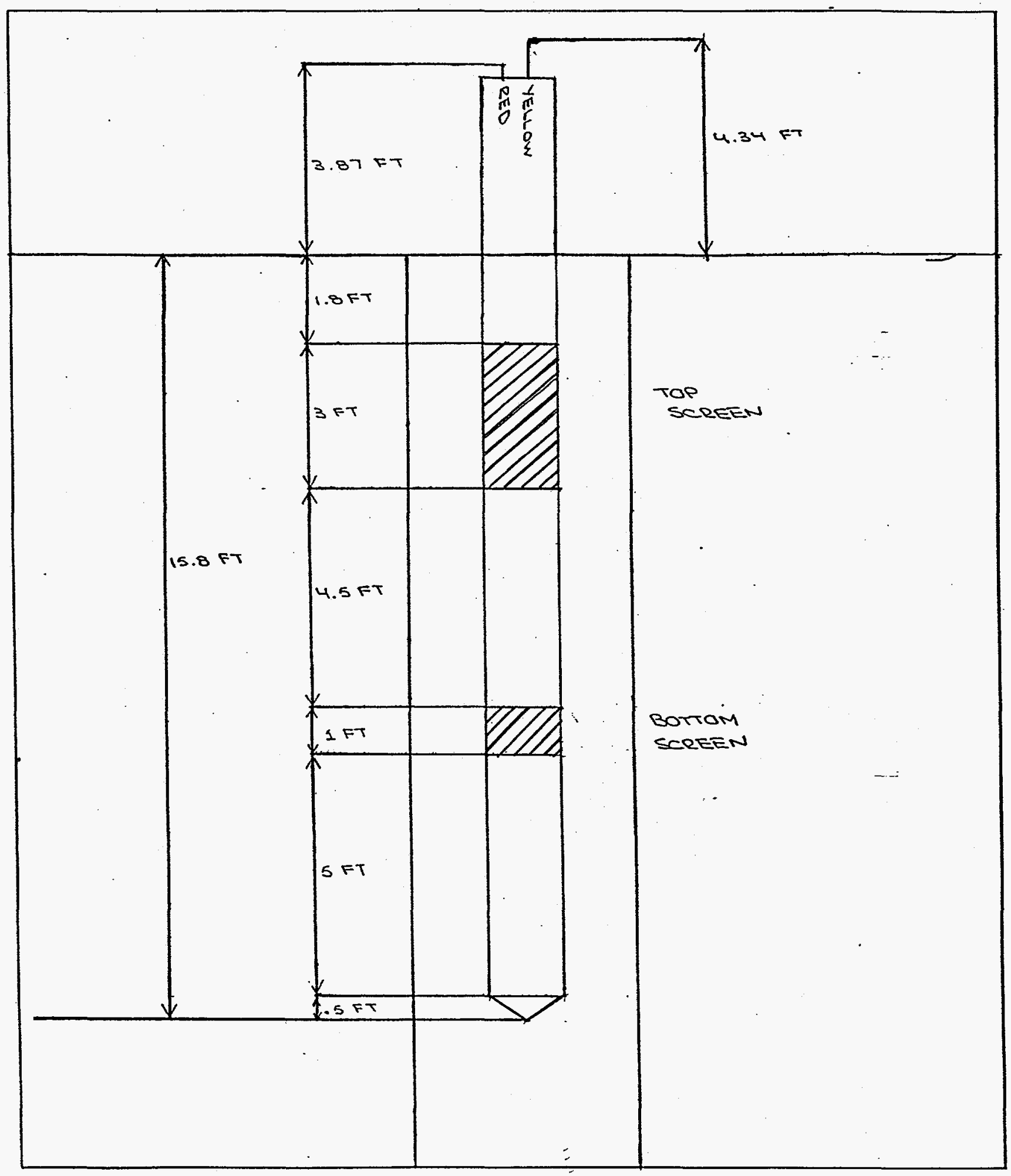




\section{Well Construction Diagram}

\begin{tabular}{|l|l|l|}
\hline Well Number: GSw03/F & Date of Installation: 10/1/97 & Horizontal Scale: \\
\hline & & Vertical Scale: $:$ \\
\hline SRS North: 64705.41 & SRS East: 64294.70 & Ground Elevation: $247.4 \mathrm{FT}$ \\
\hline
\end{tabular}

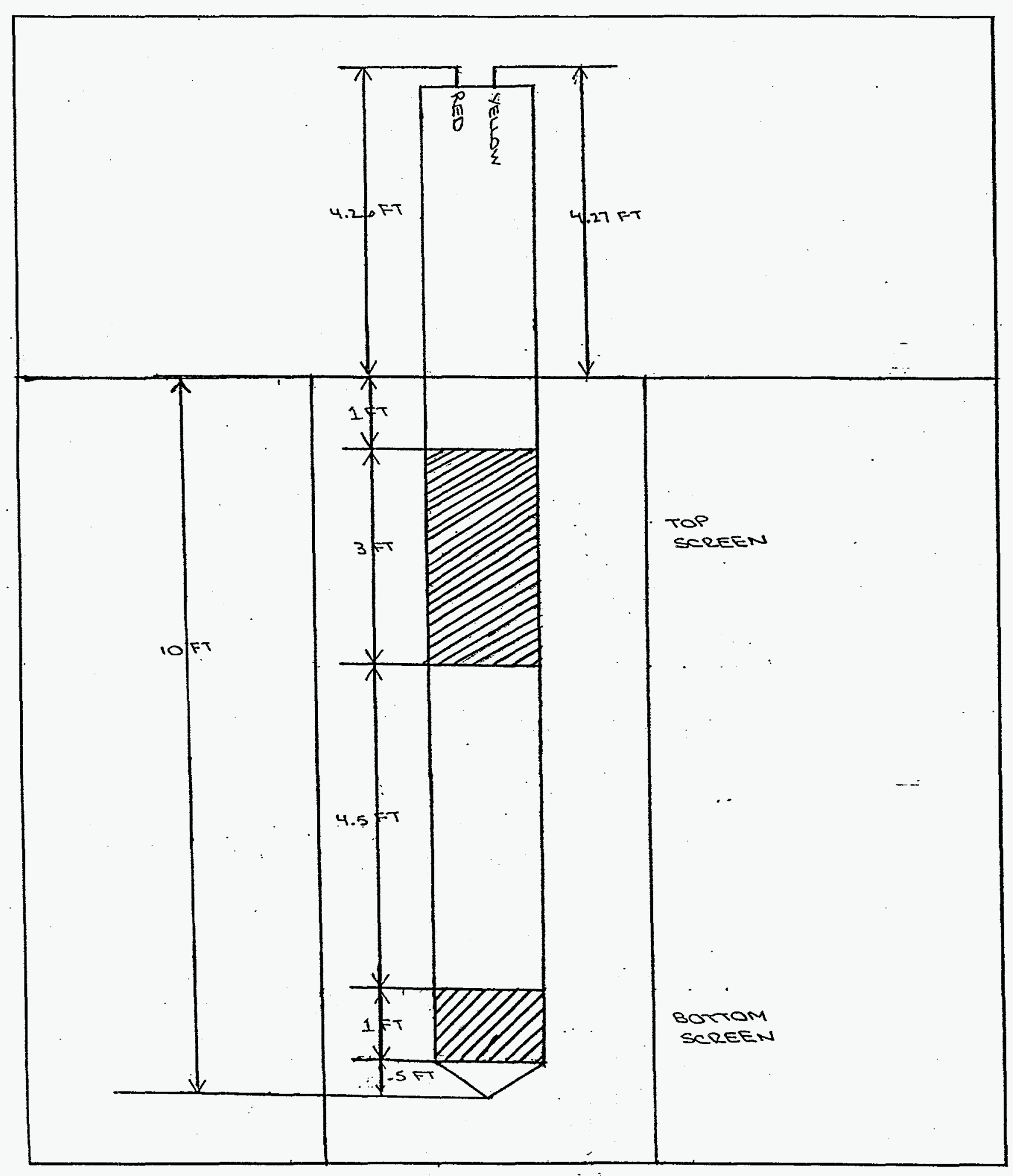


Well Construction Diagram

\begin{tabular}{|l|l|l|}
\hline Well Number: Gsw033F & Date of Installation: $9 / 30 / 97$ & Horizontal Scale: $1: 3$ \\
\hline SRS North: 64686.98 & & Vertical Scale: $1: 3$ \\
\hline
\end{tabular}

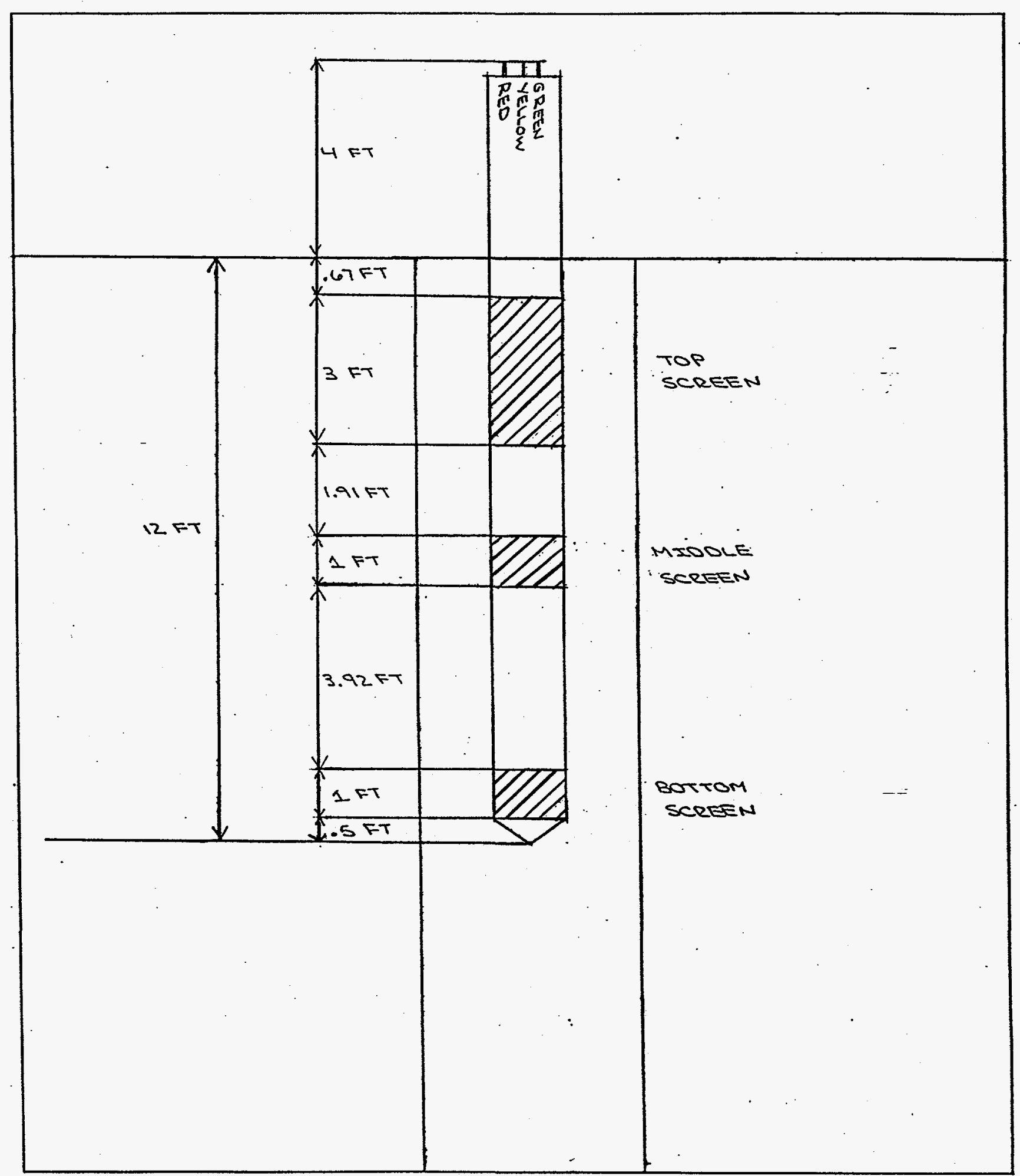

